\title{
USING DISNEY'S THEME SONG TO IMPROVE THE STUDENTS' LISTENING SKILL AT ELEVENTH GRADE OF SMAN 13 BONE
}

\author{
Andi Ahmad Mubarak ${ }^{1}$, Nirwana Darwis ${ }^{2}$, Rahmah Wahdaniati Suaib ${ }^{* 3}$ \\ 1,2,3 Department of English Education, Institut Agama Islam Negeri Bone, Indonesia \\ *Corresponding Author Email: @ rahmahwaah@gmail.com
}

\begin{abstract}
The main concern of this research was aimed at improving the listening skill of the grade XI students of SMAN 13 Bone in the academic year of 2020/2021. The researcher used WhatsApp group as a media to communicate with students, face to face cannot be implemented because of the Covid-19 pandemic. The technique of analyzing data was applied by using quantitative data. The quantitative data was taken from the test. The result shows there was a positive effect of students' listening skill using Disney's theme song. It showed from the mean of the Pre-test was 66,43 and the mean score of post-test was 78,0357. From the data, it indicated that using Disney's theme song in Listening skill was effective. The advantages of using song are: Song could become a media introduction of new languages, songs improve students' pronunciation, song could be give good contribution in increasing students' motivation in Listening, and song can strengthen memory of students.
\end{abstract}

Keyword: Disneys' theme song, Listening

\section{INTRODUCTION}

Listening plays significant role in the acquisition of the English language. The development of listening has stolen the attention of many English teachers in many countries. Generally, listening is considered as the simplest process of receiving a spoken language and also listening is considered to be the easiest skill to be mastered because it only requires short amount of time rather than the other skills which are speaking, writing and reading. Listening process in mother tongue (language) is one of the factor that support this perception because listening process in mother tongues looks easy and brief. As the matter of fact, this perception is completely not true, as stated by Ghasemboland and Nafissi (2013) a complex cognitive process needs a lot of efforts particularly in the second and foreign language learning process.

Listening is considered as an important ability that has to be mastered. Listening ability is also important to be mastered for its benefit in building a good communication. In building a good communication with others, individuals have to understand the meaning of the message conveyed by their parents when they have a conservation. In comprehending the message conveyed by the others, listening ability is needed (Hidayat;2013).

Song frequently are closer to real life experience of the students than most textbook material, with lyrics that exemplify good examples of authentic. Expert and practitioner of the language, also believes than the rhythm and authenticity of song can be used for language learning. The song's text contains real example of English usage (language is use), not to mention the pattern of sentence patterns.

Song is an important thing in learning. William (1983) stated that songs are used to achieve the relaxation and harmony needed to increase learning effectiveness. Urbanic \& Vizmuller. (1981) argues that song used was carefully chosen and prescribed to induce a mental state in which the mind was relaxed and meditative but remained receptive. The song and lyrics are an audio representation of the living language, rather than an artificially constructed pattern often found in grammar textbooks. Willis and Mason (1994) also believes that songs frequently 
IJRETAL

International Journal of Research on English Teaching and Applied Linguistics, Vol. 1, No.2, December 2020

are closer to the real life experiences of the students than most textbook material, with lyrics that exemplify good examples of authentic language.

The aim of this research is improving students listening ability through English song especially Disneys theme song. The researchers chose the Disney Theme song because it is known for its meaningful lyrics and of course it doesn't have lyrics with dirty words, unlike other western songs. The pop element in the Disney song chosen by the researcher is still very strong, so it is not boring and feels stiff, it is very suitable to be heard by young generation, especially a teenagers.

\section{RESEARCH METHOD}

This research is including of quantitative research. The quantitative data analyze in score while researcher taught the text by using Disney's Theme Song. Trough quantitative data the researcher know there is an improvement or not on the students listening skills by using Disney's Theme song. The researcher apply pre experimental research with one group pre-test and post-test design.

Population in this research is all of eleventh grade IPS of the students SMAN 13 Bone in academic year 2019/2020. It had 7 classes in eleventh grade IPS of this school. The researchers used cluster sampling. This sampling was there the selection refers to the individual rather than the group. The researcher takes 34 students from XI. IPS 3.

\section{RESULT AND DISCUSSION}

\section{A. RESULT}

Data analysis describe about listening competence to answer the question of problem statement.

To calculate the mean score and standard deviation of the students' test and score in pretest and post-test, the researcher used SPSS 23 application. Like finding out the significant different between the pre-test and post-test by calculating the value of the test and calculate the value of the test of the hypothesis concerning the different between pre-test and post-test the researcher used it also. The data is collected in order to answer the researcher question is there any effect of using disney's theme song learning student listening skill.

1. Mean Score

Table.1

Paired Samples Statistics

\begin{tabular}{|ll|l|l|l|l|}
\hline & & Mean & $\mathrm{N}$ & Std. Deviation & Std. Error Mean \\
\hline Pair 1 & pretest & 66.43 & 28 & 3.814 & .721 \\
& posttest & 78.0357 & 28 & 2.48674 & .46995 \\
\hline
\end{tabular}

Table. 1 shows the statistical summary of the students' mean score and standard deviation both in pre-test and post-test. The mean score of students' pre-test is 66.43 and in posttest is 78.0357. The students' standard deviation of pre-test is 3.814 and the post-test is 2.48674. it shows that the mean score of post-test is higher than the mean score of pretest $66.43>78.0357$. Thus, it said that there is an improvement in students' listening skill using Disney's theme song. 
IJRETAL

International Journal of Research on English Teaching and Applied Linguistics, Vol. 1, No.2, December 2020

2. The rate of percentage of the students' score in pre-test and post-test presented below:

- Pre-test

Table.2

The Frequency and Percentage of Students' score in Pre-test

\begin{tabular}{|l|l|l|l|l|}
\hline No. & Score & Classification & Pre-Test \\
\cline { 4 - 5 } & & & Frequency & Percentage\% \\
\hline 1. & $85,00-100,00$ & Excellent & & \\
\hline 2. & $75,00-84,99$ & Good & & \\
\hline 3. & $60,00-74,99$ & Enough & 34 & 100 \\
\hline 4. & $00,00-59,00$ & Poor & & \\
\hline \multicolumn{2}{|l}{ TOTAL } & & 34 & 100 \\
\hline
\end{tabular}

Table. 2 describes the value obtained by the IX IPS 3 class students on the Pre-Test. All of 34 students get a enough score, the percentage is 15 students get a score of 70 (the highest score), 12 students get a score of 65, and 7 students get a score of 60 (the lowest score) but all of them are categorized as "enough".

- Post-Test

Table.3

The Frequency and Percentage of Students' score in Pre-test

\begin{tabular}{|l|l|l|l|l|}
\hline \multirow{2}{*}{ No. } & \multirow{2}{*}{ Score } & \multirow{2}{*}{ Classification } & \multicolumn{2}{|l|}{ Pre-Test } \\
\cline { 4 - 5 } & & & Frequency & Percentage\% \\
\hline 1. & $85,00-100,00$ & Excellent & & \\
\hline 2. & $75,00-84,99$ & Good & 34 & 100 \\
\hline 3. & $60,00-74,99$ & Enough & & \\
\hline 4. & $00,00-59,00$ & Poor & & 100 \\
\hline \multicolumn{7}{|l}{ TOTAL } & & 34 & \\
\hline
\end{tabular}

Table. 3 describes the value obtained by the IX IPS 3 class students on the PostTest. All of 34 students get a good score, the percentage is 20 students get a score of 80 (the highest score), and 14 students get a score of 75 (the lowest score) but all of them are categorized as "good".

3. Test of significance

T-test value was used to know whether there was or not significant difference between pre-test and post-test in students' listening ability. 
Table.4

Paired Samples Test

\begin{tabular}{|c|c|c|c|c|c|c|c|c|}
\hline & \multicolumn{5}{|c|}{ Paired Differences } & \multirow{3}{*}{$\mathrm{T}$} & \multirow{3}{*}{$\mathrm{df}$} & \multirow{3}{*}{$\begin{array}{l}\text { Sig. (2- } \\
\text { tailed) }\end{array}$} \\
\hline & \multirow[t]{2}{*}{ Mean } & \multirow{2}{*}{$\begin{array}{l}\text { Std. } \\
\text { Deviatio } \\
\mathrm{n}\end{array}$} & \multirow{2}{*}{$\begin{array}{l}\text { Std. } \\
\text { Error } \\
\text { Mean }\end{array}$} & \multicolumn{2}{|c|}{$\begin{array}{l}95 \% \text { Confidence } \\
\text { Interval of the } \\
\text { Difference }\end{array}$} & & & \\
\hline & & & & Lower & Upper & & & \\
\hline $\begin{array}{ll}\text { Pair } & \text { pretest } \\
1 & \text { posttest }\end{array}$ & $\begin{array}{l}- \\
11.607 \\
14\end{array}$ & 4.72456 & .89286 & $\overline{13.43913}$ & -9.77515 & $\begin{array}{l}- \\
13.00 \\
0\end{array}$ & 27 & .000 \\
\hline
\end{tabular}

Based on the data in the table above shows that there is no significance difference between the students' listening skills before giving treatment. It also can be proved by the sig (2-tailed) is $0,000<0,05$. It indicated that $\mathrm{H}_{1}$ is accepted and $\mathrm{H}_{0}$ is rejected. It is assumed that there is significant different between the students' listening competence after giving the treatment.

\section{B. Discussion}

In this research , the researchers applied Disney's theme song to improve students' listening skills at SMAN 13 Bone. The researcher used online research to complete the research. It is because in 2020 has COVID-19 (Corona Virus Disease 19) that makes students have to stay at home to minimize the positive disease. Thus, the researcher conducted an online class in WhatsApp Grup to do the action research. Internet access through mobile phone devices means that such communication and information retrieval has become ubiquitous-seamlessly woven into our everyday lives. Researcher at first had a difficulties because the school had refused or prohibited researchers from researching at the school because of the holding of semester test. Although in the end the school gave permission, the research time was shortened. Monitored by homeroom teacher and English teacher, the researcher finally examined through WhatsApp group media in Class XI. IPS 3, with 34 student. The first meeting was held on Friday, 11 September 2020, during the first lesson. Because the time was shortened to only two meetings, the researcher immediately gave fourth sessions in first meeting, and three session in second meeting. The first meeting: pre-test session, first treatment, the second treatment and third treatment. At the second meeting, 18 September 2020, the researcher gave three session also at the last meeting; fourth treatment, fifth treatment, and the last is post-test. Based on the result of the pre-test before getting treatment, the students' listening competence was low. After the treatments were implemented, the students' ability was better than 
IJRETAL

International Journal of Research on English Teaching and Applied Linguistics, Vol. 1, No.2, December 2020

before. After getting the treatments and the post-test was conducted, it found that there was a difference between pre-test and post-test significantly.

The mean score of students pre-test is 66.43 and in post-test is 78.0357. The students standard deviation of pre-test is 3.814 and the post-test is 2.48674 . it shows that the mean score of post-test is higher than the mean score of pre-test $66.43>78.0357$. There is an improvement in students' Listening skill using Disney's Theme song. All of 34 students get a "Fair Score" when pre-test, the percentage is 15 students get a score of 70 (the highest score), 12 students get a score of 65, and 7 students get a score of 60 (the lowest score). And all of 34 students get a good score when post-test, the percentage is 20 students get a score of 80 (the highest score), and 14 students get a score of 75 (the lowest score). From the data, it indicated that using Disney's Theme song in Listening skill was effective.

\section{CONCLUSION}

Based on the result of analysis and discussion in the previous chapter, the researcher concluded in following description below:

The Disney theme song is a media used by researchers to determine the increase in student listening at eleventh grade of SMAN 13 Bone, from the beginning of the research through the WhatsApp group, their response was very positive. After the treatments were implemented, the students' ability was better than before. After getting the treatments and the post-test was conducted, it found that there was a difference between pre-test and post-test significantly. The students' standard deviation of pre-test was 3.814 and the post-test was 2.48674. it shows that the mean score of post-test was higher than the mean score of pre-test $66.43>78.0357$. Thus, it said that there was an improvement in students' listening skill using Disney's theme song.

\section{REFERENCES}

Hidayat, Apin. The Use of English song in teaching Student listening ability. bandung: permata. 2008.

Nafissi, F. G.The Effect of Using English Caption on Iranian EFL student "Listening Comprehension", . Procedia. 2012

Suryati, U. The Effectiveness of Using Song To Increase Student's Listening Skill, A Thesis. 2013

William. A. (Teaching in the Middle and Secondary School. New Yowk: Macmillan Publishing Company. 1983.

Willis, P \& Mason, H.A. Spoken English Learned Quickly. 1994. 